Article

\title{
Progress for On-Grid Renewable Energy Systems: Identification of Sustainability Factors for Small-Scale Hydropower in Rwanda
}

\author{
Geoffrey Gasore ${ }^{1, * \mathbb{D}}$, Helene Ahlborg ${ }^{2} \mathbb{(}$, Etienne Ntagwirumugara ${ }^{1}$ and Daniel Zimmerle ${ }^{3}$ \\ 1 African Center of Excellence in Energy for Sustainable Development, University of Rwanda, \\ Avenue de 1' Armée, P.O. Box 3900, Kigali, Rwanda; e.ntagwirumugara@ur.ac.rw \\ 2 Division of Environmental Systems Analysis, Chalmers University of Technology, \\ 41296 Gothenburg, Sweden; helene.ahlborg@chalmers.se \\ 3 Energy Institute, Colorado State University, 430 N. College Avenue, Fort Collins, CO 80524, USA; \\ dan.zimmerle@colostate.edu \\ * Correspondence: g.gasore@ur.ac.rw; Tel.: +250-786585881
}

check for updates

Citation: Gasore, G.; Ahlborg, H.; Ntagwirumugara, E.; Zimmerle, D. Progress for On-Grid Renewable Energy Systems: Identification of Sustainability Factors for Small-Scale Hydropower in Rwanda. Energies 2021, 14, 826. https://doi.org/ $10.3390 /$ en 14040826

Academic Editor: José Matas Received: 27 October 2020 Accepted: 25 December 2020 Published: 5 February 2021

Publisher's Note: MDPI stays neutral with regard to jurisdictional clai$\mathrm{ms}$ in published maps and institutional affiliations.

Copyright: (C) 2021 by the authors. Licensee MDPI, Basel, Switzerland. This article is an open access article distributed under the terms and conditions of the Creative Commons Attribution (CC BY) license (https:// creativecommons.org/licenses/by/ $4.0 /)$.

\begin{abstract}
In Rwanda, most small-scale hydropower systems are connected to the national grid to supply additional generation capacity. The Rwandan rivers are characterized by low flow-rates and a majority of plants are below $5 \mathrm{MW}$ generation capacity. The purpose of this study is to provide a scientific overview of positive and negative factors affecting the sustainability of smallscale hydropower plants in Rwanda. Based on interviews, field observation, and secondary data for 17 plants, we found that the factors contributing to small-scale hydropower plant sustainability are; favorable regulations and policies supporting sale of electricity to the national grid, sufficient annual rainfall, and suitable topography for run-of-river hydropower plants construction. However, a decrease in river discharge during the dry season affects electricity production while the rainy season is characterized by high levels of sediment and soil erosion. This shortens turbine lifetime, causes unplanned outages, and increases maintenance costs. Further, there is a need to increase local expertise to reduce maintenance cost. Our analysis identifies environmental factors related to the amount and quality of water as the main current problem and potential future threat to the sustainability of small-scale hydropower. The findings are relevant for energy developers, scholars, and policy-makers in Rwanda and East Africa.
\end{abstract}

Keywords: small-scale hydropower plants; sustainability factors; on-grid systems; smart grids; Africa; Rwanda

\section{Introduction}

Africa has large untapped renewable energy potential that can help achieve energy access for all and catalyze social and economic development while keeping greenhouse gas emissions at low levels. However, rapid urbanization with an expected additional 500 million people moving to cities will incur a great demand for transport and building construction, while higher temperatures increase the need for cooling services. The continent's increasing demand for electricity, fuel, and construction materials led the International Energy Agency [1] to state that the energy pathway chosen by African countries will have a global impact and significantly influence the time it takes to achieve a carbon-neutral energy sector worldwide. While the responsibility for reducing emissions of greenhouse gases rest heavily on industrialized nations, the effects of increasing average temperatures are already affecting life and well-being on the continent.

This research deals with the current development and sustainability factors for smallscale hydropower plants in Rwanda, an East African country with high hydropower resource potential, ambitious national targets, and a strong development of the hydropower sector. Rwanda is unique in the East African context in that most current small-scale 
hydropower systems are connected to the national grid, supplying additional generation capacity at a guaranteed price. Rwanda possesses 333 potential sites for hydropower, the majority being at the scale of micro and mini-i.e., with potential generation capacity below 5 MW. Rwanda may develop a country-wide integrated network of distributed generation. In combination with rapid development in solar, a vision of 100 percent renewable energybased electricity generation is within reach. However, small-scale hydropower plants face contextual challenges that negatively affect the sustainability of such systems. This study investigates both positive and negative factors affecting the sustainability of Rwanda's small-scale hydropower plants from a utility perspective, providing the hitherto most comprehensive study of on-grid small hydro in the East African region.

The majority of rivers in Rwanda have relatively low flow rates: $0.05 \mathrm{~m}^{3} / \mathrm{s}$ to $7.14 \mathrm{~m}^{3} / \mathrm{s}$ in the rainy season, with a high degree of flow variability between wet and dry seasons (typically $>50$ percent decrease in the dry season). Globally, the most often used definition of small scale hydropower plants is hydropower units with a rated capacity of $10 \mathrm{MW}$ or less, but many countries have their own classification reflecting the local situation [2]. In Rwanda, there is no established country definition for the limit of small scale hydropower plants [3]. In this study, we define small scale hydropower plants as plants with $<5 \mathrm{MW}$ in capacity. These can be further subdivided into Pico $(<10 \mathrm{~kW})$, micro $(10-100 \mathrm{~kW})$, mini (100-1000 kW) and small (1000-5000 kW). The $5 \mathrm{MW}$ limit on small-scale hydropower plants is based on the low flow rate of most rivers. The majority of existing hydropower plants are below $5 \mathrm{MW}$, with a few larger plants between 9.5-28 MW. Table 1 summarizes data on the country's 30 deployed hydropower plants by 2019, with installed capacity, type of ownership, year of commissioning, storage type, and supply model $[4,5]$.

Table 1. Characteristics of deployed hydropower plants in Rwanda for both small and big plants.

\begin{tabular}{|c|c|c|c|c|c|c|}
\hline $\mathbf{s} / \mathbf{n}$ & Plant Name & Installed Capacity (MW) & Year Commissioned & Storage Type & Ownership & Grid/Off-Grid \\
\hline 1 & Nyabarongo I & 28 & 2014 & Reservoir & Government & Grid \\
\hline 2 & Mukungwa I & 12 & 1982 & Reservoir & Government & Grid \\
\hline 3 & Rusizi II & 12 & 1984 & Reservoir & Regional & Grid \\
\hline 4 & Ntaruka & 11.25 & 1959 & Reservoir & Government & Grid \\
\hline 5 & Rukarara I & 9.5 & 2010 & Reservoir & Private & Grid \\
\hline 6 & Giciye I & 4 & 2013 & Run-off & Private & Grid \\
\hline 7 & Giciye II & 4 & 2016 & Run-off & Private & Grid \\
\hline 8 & Rugezi & 2.6 & 2011 & Run-off & Private & Grid \\
\hline 9 & Rwaza Muko & 2.6 & 2018 & Run-off & Private & Grid \\
\hline 10 & Mukungwa II & 2.5 & 2013 & Run-off & Private & Grid \\
\hline 11 & Keya & 2.2 & 2011 & Run-off & Private & Grid \\
\hline 12 & Rukarara II & 2.2 & 2013 & Run-off & Private & Grid \\
\hline 13 & Gihira & 1.8 & 1984 & Run-off & Private & Grid \\
\hline 14 & Gisenyi & 1.2 & 1957 & Run-off & Private & Grid \\
\hline 15 & Nkora & 0.68 & 2011 & Run-off & Private & Grid \\
\hline 16 & Gaseke & 0.582 & 2017 & Run-off & Private & Grid \\
\hline 17 & Mazimeru & 0.5 & 2012 & Run-off & Private & Grid \\
\hline 18 & $\begin{array}{l}\text { Nyirabuhom- } \\
\text { bohombo }\end{array}$ & 0.5 & 2013 & Run-off & Private & Grid \\
\hline 19 & Musarara & 0.45 & 2013 & Run-off & Private & Grid \\
\hline 20 & Nshili I & 0.4 & 2012 & Run-off & Government & Grid \\
\hline 21 & Cyimbili & 0.3 & 2011 & Run-off & Private & Grid \\
\hline 22 & Agatobwe & 0.2 & 2010 & Run-off & Private & Grid \\
\hline 23 & Mutobo & 0.2 & 2009 & Run-off & Private & Grid \\
\hline 24 & Nyabahanga I & 0.2 & 2012 & Run-off & Government & Grid \\
\hline 25 & Gashashi & 0.2 & 2013 & Run-off & Private & Grid \\
\hline 26 & Janja & 0.2 & 2012 & Run-off & Private & Grid \\
\hline 27 & Murunda & 0.1 & 2010 & Run-off & Private & Grid \\
\hline 28 & Nyamyotsi I & 0.1 & 2011 & Run-off & Private & Grid \\
\hline 29 & Nyamyotse II & 0.1 & 2011 & Run-off & Private & Grid \\
\hline 30 & Ecos & 0.011 & 2016 & Run-off & Private & Off-Grid \\
\hline
\end{tabular}


Most existing small-scale hydropower plants are implemented as "run-of-river" plants. Run-of-river hydropower plants generate electricity by the immediate use of the inflows and have little or no reservoir storage capacity [2]. Therefore, run-of-river hydropower plants are subjected to weather and seasonal variations, resulting in seasonal variation in power generation. The steepness of the terrain leading to small and heavily populated valleys makes large storage reservoirs difficult to implement. Some evidence [2] indicates that this type of plant is very cost-effective and has few negative impacts on the environment and river ecosystem compared to larger hydropower with dam infrastructure that floods a large area. Additionally, these systems require relatively small investments, involve fewer construction activities, and need less maintenance. Further, Table 1 shows that the development of privately-owned plants is notably strong in the last decade. This coincides with good economic performance (with an average GDP growth rate of around 8 percent per year from 2000 to 2015), and the introduction of policies to encourage private sector involvement and the leasing of government-owned hydropower plants to private power developers [6-8]. In addition, the country has set an ambitious energy development agenda to meet a 100 percent electrification target by 2024, and the rate of development has been rapid in the last 10 years. National access was estimated at 10 percent in 2009 and reached 52 percent in 2019, while generation capacity grew from $88 \mathrm{MW}$ in 2010 to $221 \mathrm{MW}$ in 2019 [9-11].

This rapid increase in electricity access is a result of government initiatives and new energy policies, such as the Energy Sector Strategic Plan (2015), the Rural Electrification Strategy (2016), and the National Strategy for Transformation (2017), establishing the target of 100 percent electricity access by 2024. This is suggested to be achieved with 52 percent of the population reached by the national grid and 48 percent being supplied with off-grid services. A Renewable Energy Feed-in Tariff for small and mini-hydropower was issued in February 2012 [7,12-14]. This regulation attracted many independent power producers (IPPs) leading to growth in the sector.

The objective of this research is to first, identify environmental, technical, economic, institutional, and social factors affecting the operation and sustainability of deployed smallscale hydropower plants in Rwanda. Secondly, it describes the interconnection with the national grid and analyses the consequences thereof. The scope of the study includes both positive and negative factors affecting system operation. Potential factors were identified based on literature review and investigated through site observation and interviews with plant operators and company technical directors. Since almost all the plants are gridconnected, users receive electric services from Rwanda Energy Group (REG) through the national grid and not from the plants directly, except for off-grid plants. This study is thus limited to investigating operational issues from the plant operator's point of view, excluding the perspectives of users. Another limitation of the study is the exclusion of effects that plants may have on the natural environment and river system, focusing instead on the ways in which environmental factors affect the plants.

The sustainability factors of small-scale hydropower plants have been discussed in previous literature, with examples from all over the world. This section focuses primarily on literature discussing small scale hydropower in rural and poor community contexts. Our understanding of sustainability builds, for this study, on work and previous definitions of sustainability, as applied to small-scale electric power plants in a developing economy context. The UN commission on sustainable development describes sustainability in five dimensions: technical, economic, social, environmental, and institutional [15]. Building on these, Ilskog et al. [16] evaluate the sustainability of rural electrification systems as follows: technical sustainability, which relates to maintaining the energy service at a certain quality through its lifetime of the investment; economic sustainability, which focuses on the survival of the service beyond the economic lifetime of the initial investment; social sustainability, which focuses on equitable distribution of the benefits offered by electrification; environmental sustainability, mainly focused on the conservation of natural resources and minimizing negative environmental impact; institutional sustainability, 
involving the survival of the organization and its ability to maintain adequate performance with respect to other dimensions of sustainability [16]. Based on these five dimensions of sustainability, we can notice that three of them (technical, economic, and institutional) focus on the sustainability of the electric power system as such. Social and environmental dimensions are considering the effects of the power production and distribution on society and nature, which are outside of the scope of this study. We are, however, interested in the effects that the natural environment may have on the technical system, in terms of environmental factors affecting technical, economic, and institutional sustainability of the plant and utility organization. We may also expect that social and cultural factors influence the economic and institutional sustainability of hydropower. In the following, we include only factors that affect the system over its lifetime, while we exclude for example financial, social, or institutional barriers that prevent construction of new infrastructure.

The review of previous literature was carried out based on searches in Google Scholar and Scopus, using the following key words combined using Boolean operators into different search strings: hydro potential; hydropower AND small scale OR small OR mini OR micro OR Pico; sustainability AND issues OR drivers OR factors OR barriers; developing countries; Africa OR Sub-Saharan Africa OR East Africa OR Rwanda; operational OR performance OR viability OR reliability OR profitability. 77 published resources were reviewed including: scientific articles on small-scale hydropower in low- and middle-income countries (26 articles); scientific articles with broader focus on distributed generation (23 articles); and relevant but not peer-reviewed literature (28 publications, including reports and conference proceedings). The list of papers is provided in Supplementary Materials.

Previous literature identifies a range of factors affecting the technical sustainability of plants. These are commonly linked to resource potential, design, technical reliability, or managerial capacity. Singh et al. [17] identified head, river discharge, turbines, and generators as the major parameters that affect the operation of hydropower plants. Negative factors are negligence in the construction of mini hydropower plants, low plant capacity factor, [18] overestimation of plant capacity resulting from low quality of pre-studies, and limited capacity in plant construction and design [19]. During operation, challenges include long breakdown periods, low efficiency, carelessness, and inefficient operation [18]. Besides the importance of feasibility studies and good technical design, Didik et al. [20] mention the availability of operation and maintenance funds, and good managerial capacity. Many studies point to the generic importance of the availability of adequate technical knowledge and skills, and well as access to spare parts [16,21,22].

Environmental factors relate primarily to water discharge and sediment levels. For example, Luis et al. [23] identify increasing inflow of sediment year after year as a sustainability challenge. Thakur et al. [24] find that silt in river water is among the key factors that cause rapid wear and premature failure of turbines. Similarly, the authors argue that wear by silt affects turbine performance, with variations in erosive wear depending on silt concentration, silt size, stream velocity, and working time.

Previous studies identify economic barriers to both investment and operation of smallscale plants, with a major hurdle being a weak customer base (especially in off-grid rural areas with customers of low purchasing power) which affect utility income in both short and long-term perspectives [25]. Economic issues are interlinked with institutional issues, as utility income affect managerial capacity and organizational development and vice versa. Ahlborg and Sjöstedt [26] note the importance of coupling energy programs with complementary activities such as education and agricultural processing while identifying negative factors such as lack of local managerial capacity and business skills as threats to the sustainability of rural micro-grids. Institutional sustainability factors are considered very important [26] for long-term functioning of utility organizations, with type of ownership, decision-making, and mechanisms for community participation making a difference for ability to handle challenges such as free riding and the risk of elite capture. Likewise, Terrapon-Pfaff et al. [21] mention importance of network connections and the commitment of the implementing organization. The question of local participation is brought up in 
many studies as a social and institutional factor that can work either as driver or barrier to sustainability, however, many previous studies concern off-grid hydropower systems with distribution to local customers [26,27] whereas on-grid systems in Rwanda do not sell to local customers. There is a lack of studies comparing on and off-grid hydropower and it is thus an open question if on-grid systems face the same challenges or not.

There are very few scientific studies of small-scale hydropower plants in Rwanda, with most of the previous literature composed of consultancy reports, government reports, single case studies, master theses, and conference papers. For example, Maurice et al. [28] examine private sector participation in micro-hydropower plants development in Rwanda. The study suggests proper institutional arrangements, local participation at all levels and in all project phases, and good collaboration between local people and firms in both private and financial sectors as sustainability solutions. The study does not consider technical and environmental factors affecting sustainability of small-scale hydropower plants. Geoffrey et al. [29] describe development trends of small-scale hydropower plants in Rwanda, identifying causes of the rapid development happening since 2007 and available opportunities and challenges. The same study does not, however, consider factors influencing the sustainability of existing plants. Bensch et al. [11] examine social-economic impacts of rural electrification in Rwanda but do not analyze the sustainability of generation systems. The review shows that the current base of evidence regarding factors influencing sustainability of small-scale hydropower plants in the East African region is limited and not strong enough to support effective policy or sector advice. The knowledge gap for Rwanda is even more pronounced and no studies to date investigate the sustainability of on-grid small-scale hydropower plants development in the region. Most studies are still focused on technical and economic factors, with less attention given to social or institutional factors. Some studies concern environmental factors related to soil erosion, discussing effects on the technical system $[30,31]$.

This study aims to contribute to improved understanding of what role hydropower currently plays and can play in the future for Rwanda's energy system. This is the first study to evaluate the sustainability of the deployed small-scale hydropower plants in Rwanda. Taking stock of the current situation is necessary to plan for future development of the resource potential, some of which would be on-grid and some of which would be off-grid.

We apply a sociotechnical approach based on previous work by Ahlborg [26] and see electric power systems as interacting with the local context in a complex process involving humans, nature, and technology. This involves seeing the different dimensions of sustainability as systemic and to consider how interactions change over time and with place. Factors are also cross-scale which means that factors originating at higher levels (regional climate patterns, national legislation, international programs for financing renewable energy, etc.) can have very direct, localized effects. A systems analysis explicitly considers what multi- and cross-scalar relations imply for preconditions and sustainability outcomes for a specific electric power system. Rather than considering sustainability "indicators" as analytically separate which is the case in e.g., Ilskog et al. [15], we thus expect that there will be connections between them: trade-offs, contradictions, synergies, and sequential relations. The extent to which such dynamics are captured in the data is highlighted in the result section and discussion.

The significance of this research is that it presents results from a comprehensive empirical study of existing small-scale hydropower plants in Rwanda, assessing the main factors affecting their operation and prospects for working sustainably their entire technical system lifetime, with data from 17 out of the country's 25 plants. Undertaken in connection to a technical assessment of silt and sediment levels in rivers and the effect on turbine functioning, this qualitative study investigates the relative importance of sustainability factors, from the perspective of utility companies. This study targets energy developers, scholars, and energy sector stakeholders in Rwanda and the wider sub-Saharan region. 


\section{Methods}

Rwanda is located in the eastern part of Africa with an area of $26,338 \mathrm{~km}^{2}$ and an average altitude of about $1700 \mathrm{~m}$. The population is estimated to be around 12.8 million as of February 2020 [32]. Precipitation ranges from 1000 to $1400 \mathrm{~mm}$ (40 to 55 inches) per year depending on the area [33]. Rwanda is among the fastest-growing economies in sub-Saharan Africa (SSA), with a GDP amounting to 10 billion USD and a GDP growth of 8.6 percent in 2018 (World Bank, 2019). The service sector is the leading contributor to the GDP (49 percent), followed by agriculture (27 percent) and industry (17 percent), with 7 percent attributed to adjustment in taxes and subsidies on products [10].

Using a mixed-methods approach, we identified factors currently affecting the operation of studied plants. The study design sought to include all of the existing 25 small-scale hydropower plants in the country. This purposive method for sample determination allowed flexibility for working with those who were willing to respond and allowed us to select respondents with specific skills.

Secondary data [4] were used to identify and preliminarily classify existing small-scale hydropower plants. The majority are located in western Rwanda, an area with higher precipitation, more rivers, and larger elevation changes than in eastern Rwanda as seen.

The first author approached all hydropower plant owners countrywide for permission to survey their assets. Owners of 17 of 25 hydropower plants agreed. The plants' geographical distribution is shown in Figure 1.

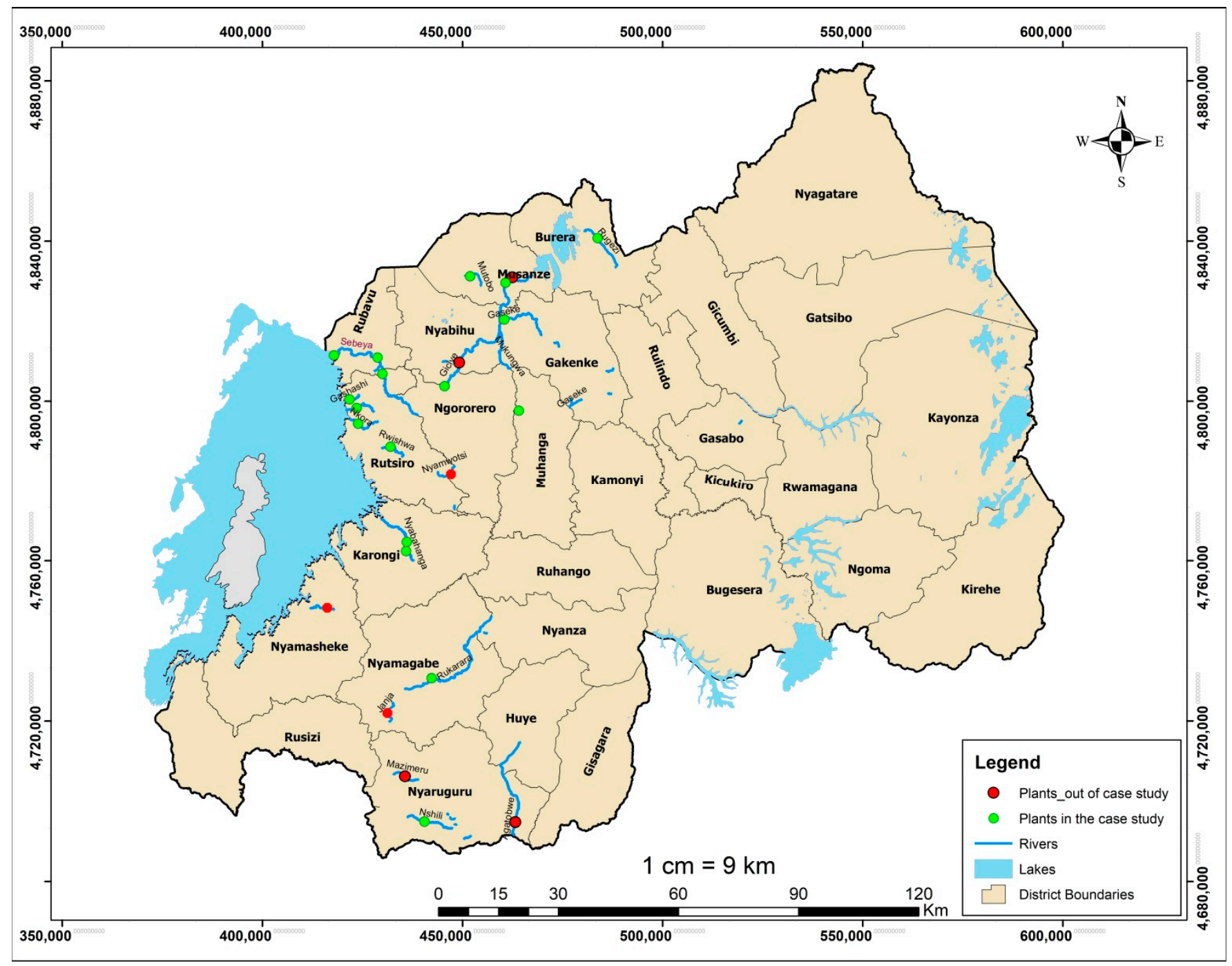

Figure 1. Map showing deployed small-scale hydropower plants included in the sample study and plants not included in the study. 
The first author conducted two rounds of interviews, first in meetings with each company technical director. Interviews were carried out using a printed questionnaire in English, with respondents answering in Kinyarwanda. The first author took notes and afterwards translated notes to English. While interviewees answered many questions during the first interview, some required technical data that was not available or not known to the interviewee. To complete the technical questions, the questionnaire was sent to each company by email, asking respondents to return answers by email. While all respondents replied, answers were short and incomplete. The first author then scheduled visits at all 17 hydropower plants. Each plant was visited two times, once each in dry and rainy seasons. During the visit, the first author conducted interviews with technical staff on site to validate and clarify the previous answers. The questionnaire included mostly open-ended questions in a semi-structured format, and the interviewer posed follow-up questions to probe any new issues that emerged during the interviews. This allowed for further explanations and possibility to follow up on issues not included in the questionnaire. The following themes were covered in these interviews on site: plant technical characteristics and current status, maintenance, technical problems (including reasons for these), repair activities, other sustainability problems (including issues outside the control of operators), and sediment questions (including infrastructural design to reduce sediment levels in the turbine). The respondents were also asked to compare the importance of silt wear in comparison to other technical problems. The interview questionnaire used is included in the Supplementary Materials. The information on policy/regulations for IPPs and small-scale hydropower plants comes from secondary data.

Twenty-six respondents participated in in-person interviews and visits; eight were managerial personnel at the level of technical director or company manager who were interviewed in corporate offices, 14 were technicians assigned to plant operations who interacted during field visits, two were owners of the company, and two were managers in the generation division of the REG. (Note that some companies own more than two plants and interviews with technical directors or managers may cover multiple plants.)

In connection to interviews, the first author used field observation at the powerhouse and intake to complement interview responses with photos, notes, and open-ended discussion with the plant managers and technicians. This auxiliary documentation and supplemental discussion were used to validate questionnaire responses and improve the first author's understanding of each plant's characteristics and issues. Following the field visits, responses were further clarified through follow up questions by phone or email, as required. Additionally, at seven sites additional time was spent conducting technical measurements of river discharge.

The one-day plant visits took place in April-May 2019 (rainy season) and June-August 2019 (dry season). The first author also spent one month (October 2019) as a guest at one micro-hydropower plant, following daily operation to fully understand the effect of flow rate variation and grid issues on plant operation. In total, 90 days were spent in the field for data collection during 2019. Finally, the data was also reviewed with experts at the REG, with specific attention paid to operational challenges related to grid integration discovered during field visits.

The analysis is based on a content analysis approach to interview data collected in field work [34]. The interview responses were coded using an excel sheet, where we organized all answers thematically, question by question, and according to respondent. The answers were summarized for each question and together the authors scrutinized the meaning and interpretation of all answers. Sustainability factors are analyzed based on the frequency by which a factor occurred in responses, and the importance attributed to them by respondents. Factors are also analyzed in terms of their origin and effect when such explanation was given by respondents. Some sustainability dimensions are interlinked and feedback between them shape outcomes over time. For example, the choice of turbine and design of the intake influence the degree of maintenance needed, with consequences for both costs and required local technical expertise. System dynamics are context-specific 
and change over time, which means that in-depth case assessments require the collection of significant amounts of data at multiple points in time [26]. Given the broad scope with 17 hydropower plants, it is not feasible to provide in-depth analysis for each case and sustainability dimension. The use of qualitative interviews has some advantages in this situation, as questions and answers can address the current situation and development over time and retrospectively discuss causes and effects. There may still be issues that were overlooked, misunderstood, or not understood in enough depth. Another limitation has to do with documentation of interviews where it was not possible to record the interviews, which limits original data to notes and photos taken by the first author. The site visits at most plants were also relatively short, limiting time for interviews and observation to a few hours.

\section{Results}

To capture the system interactions between human, technological, and environmental components, we organized results schematically, considering the hydropower plant itself as the main system, which is connected to two other physical systems that are largely outside the control of local operators and plant owners; the upstream river system and the 'electrically downstream' national grid. In the following sections, we provide a description of the plants' technical characteristics and then discuss factors originating with the river system and their impact on plant infrastructure and operations; factors originating in the hydropower plant itself, and last; factors related to the plant's grid connection. Economic and institutional factors are cross-cutting, sometimes cross-scale, and highlighted throughout.

\subsection{Plant Technical Characteristics}

The first characterization of the studied plants shows that a majority are privatelyowned and were developed in the last ten years. Table 2 shows that all seventeen (17) plants are run-of-river type and sixteen (16) out of seventeen (17) plants are grid-connected. Notably, the figures on generation capacity show that there is a considerable decrease in river discharge leading to a 40 percent decrease, on average, in generation during the dry season, and a corresponding decrease in the annualized plant capacity factor.

Table 2. Plants in the sample study technical characteristics and current status.

\begin{tabular}{|c|c|c|c|c|c|c|c|}
\hline \multirow{2}{*}{$\mathbf{S} / \mathbf{N}$} & \multirow{2}{*}{ Plant Name * } & \multirow{2}{*}{$\begin{array}{c}\text { Connection } \\
\text { Type }\end{array}$} & \multirow{2}{*}{ Ownership } & \multirow{2}{*}{$\begin{array}{c}\text { Installed } \\
\text { Capacity }(\mathbf{k W})\end{array}$} & \multicolumn{2}{|c|}{ Generation $(\mathrm{kW})$ at Time of Visit } & \multirow{2}{*}{$\begin{array}{l}\text { Capacity-Factor } \\
\text { (Percent) }\end{array}$} \\
\hline & & & & & Rainy Season ${ }^{1}$ & Dry Season $^{2}$ & \\
\hline 1 & ECOS & off-grid & Private & 11 & 11 & 10 & \\
\hline 2 & Maranda & grid & Private & 100 & 90 & 45 & 45 \\
\hline 3 & Mutobo & grid & Private & 200 & 180 & 90 & 45 \\
\hline 4 & Gashashi & grid & Private & 200 & 170 & 80 & 40 \\
\hline 5 & Nyabahanga & grid & Public & 200 & 200 & 110 & 55 \\
\hline 6 & Cyimbili & grid & Private & 300 & 270 & 150 & 50 \\
\hline 7 & Nshili & grid & Public & 400 & 300 & 240 & 60 \\
\hline 8 & Gaseke & grid & Private & 582 & 320 & 135 & \\
\hline 9 & Nkora & grid & Private & 680 & 500 & 340 & 50 \\
\hline 10 & Gisenyi & grid & Private & 1700 & 1700 & 780 & 65 \\
\hline 11 & Gihira & grid & Private & 1800 & 1700 & 1260 & 70 \\
\hline 12 & Keya & grid & Private & 2200 & 1900 & 1100 & 50 \\
\hline 13 & Rukarara II & grid & Private & 2200 & 2000 & 1155 & 52.5 \\
\hline 14 & MukungwaII & grid & Private & 3600 & 3400 & 1825 & 73 \\
\hline 15 & Rugezi & grid & Private & 2600 & 2400 & 1300 & 50 \\
\hline 16 & Rwaza Muko & grid & Private & 2600 & 2200 & 1560 & 60 \\
\hline 17 & Giciye I & grid & Private & 4000 & 3600 & 1600 & 40 \\
\hline \multicolumn{4}{|c|}{ Totals: } & 23,373 & 20,941 & 11,780 & \\
\hline \multicolumn{4}{|c|}{ Fraction of Installed Capacity: } & & 90 percent & 50 percent & \\
\hline
\end{tabular}

Note: * All plants are run-of-river designs with no storage reservoir. ${ }^{1}$ Rainy season visits happened in April and May. ${ }^{2}$ dry season visits happened in Jun and August. Plant capacity factor data are from secondary data since it can't be calculated from the field visits data [4]. 


\subsection{Effects of the River System on Hydropower Plant Performance}

The interviews with technical directors and plant managers revealed the importance of water-related factors that are partly or fully outside of the control of local plant operators and owners of the plants. These factors are conveniently divided into two subclassifications: (a) environmental conditions which impact seasonal river flows, and (b) the socio-economic context which impacts human activities near the river, upstream of the plant.

First, environmental conditions pose challenges that are mostly seasonal. Most importantly, low river discharge during the dry season and solid waste (e.g., tree branches) in the river during rainy season are major causes of poor plant performance. The importance of these problems can be seen from interviewees' answers in Figure 2 regarding problems caused by factors that operators cannot control, as well as in Figure 3 showing pictures taken during field observation.

Big drop in discharge during dry season, grid issues, and soil erosion (heavy garbage and sediments) are the most significant factors affecting negatively the sustainability of small-scale hydropower plants in Rwanda. Although water competition was not reported to be a big issue to the sustainability of small-scale hydropower plants, it is likely to be a big issue in the near future since all hydropower plants were designed for available maximum discharge. There is a reasonable increase in water use by municipalities for domestic use and such use is a priority for river water usage in Rwanda [35].

These problems are not easily solved through design measures but can be mitigated. Among positive environmental factors, the results indicate sufficient annual average rainfall and suitable head for run-of-river systems. For instance, the data indicate that plants are designed for maximum annual flows; on average the 17 hydropower plants in the study produce 90 percent of design capacity during the wet season visit. Since run-of-river hydropower plants have no water storage, river flow depends on direct runoff and limited groundwater injections into the river, resulting in a dry season generation capacity that is approximately half the capacity during the wet season. Due to the large decrease in river flow during the dry season, plants often cannot run continuously and must stop periodically to allow the forebay to fill. This reduces the dry season capacity factor further.

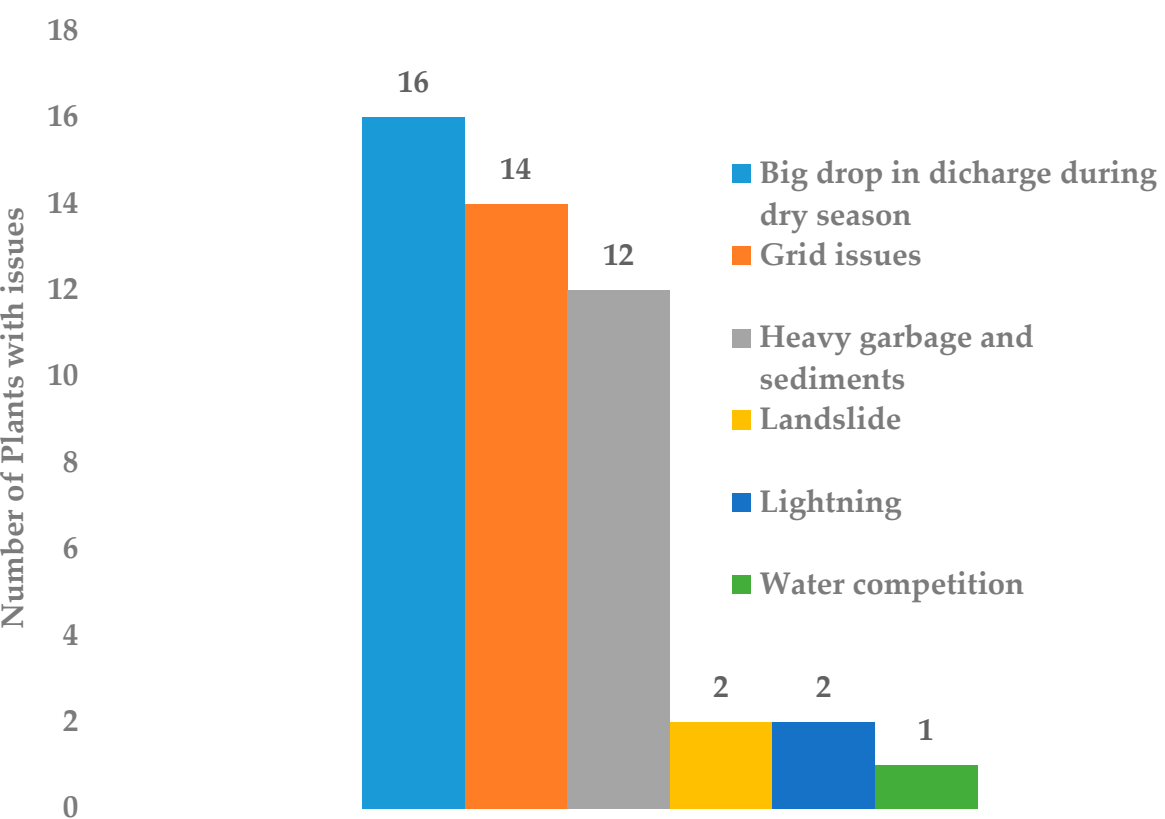

Figure 2. Interview results on factors outside operator's control. Figure 2 reports the answers to the question: Did you have any problems with the plant or the grid caused by factors that you/the operator could not control? Respondents could give multiple answers and follow-up questions were also asked to ensure a wider set of factors were considered. 

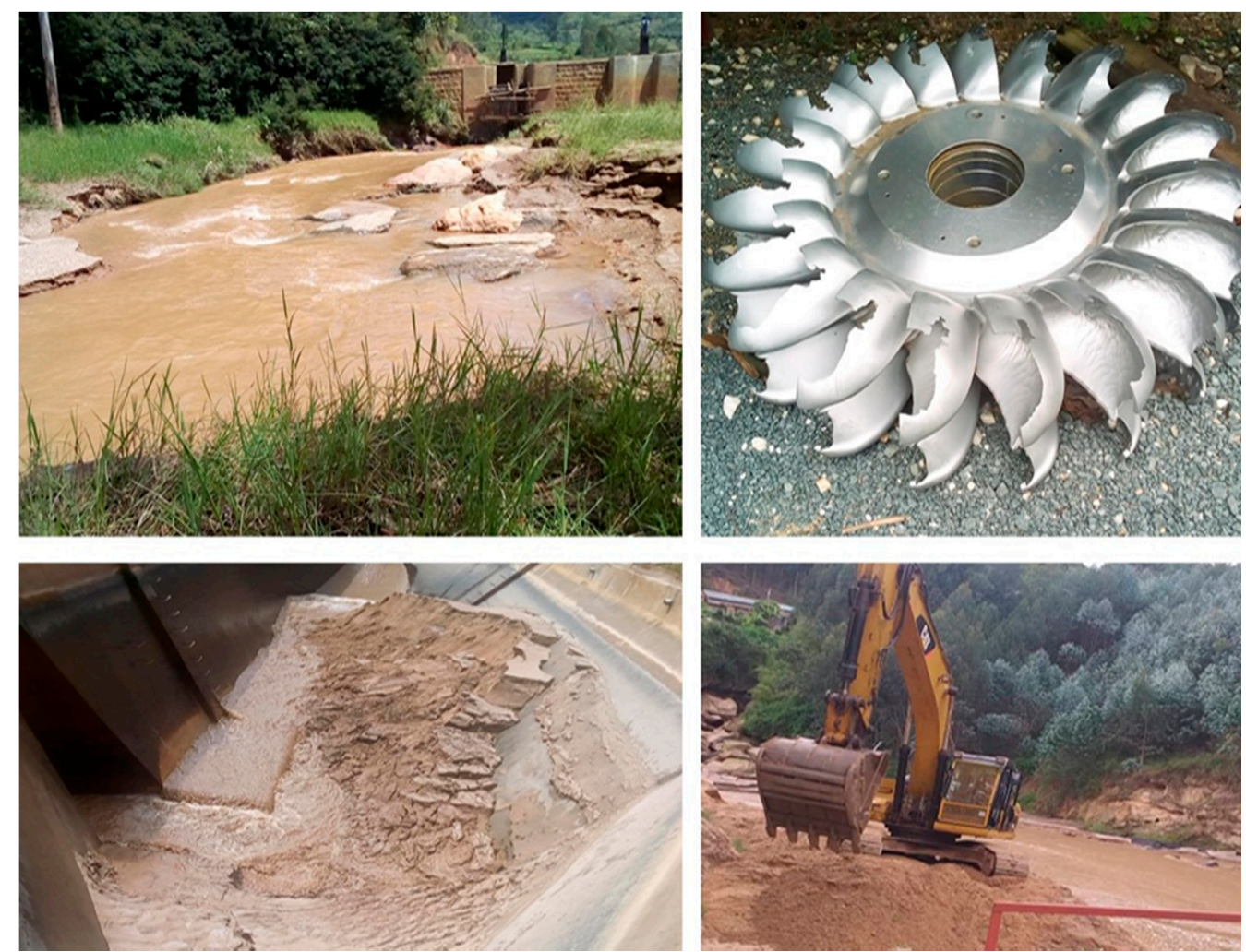

Figure 3. Field observation on soil erosion, sediments, and turbine wear. Clockwise from upper left: an upstream catchment filled with sediments and soil erosion during one rainy season, turbine runner wear due to waterborne sediment after 1.5 years in operation, heavy equipment removing sediments from another upstream catchment, and a sediment basin filled by sediments over three days during rainy season.

Second, human activities upstream of hydropower plants result mainly from the main economic activity of farming. According to Rwandan law, human activities are forbidden within $50 \mathrm{~m}$ of rivers, but in practice, land next to rivers is commonly used for farming and animal grazing. More than 80 percent of small-scale hydropower plants are located in the northern and western part of Rwanda where many districts are classified as soil erosion risk zones, due to hilly topography, steep slopes, and high annual rainfall which combine to erode soil that is not covered by dense vegetation [36].

As described by Karamage et al. [37], current human farming activities without erosion mitigation practices are causing high sediment loads in the rivers and, in areas where vegetation cover is cleared and the soil parent material is prone to sliding (the lithology type being Gneiss or Schists), heavy rains provoke the occurrence of landslides [33]. Two respondents stated that landslides increased repair costs during their plant's operation.

High sediment levels in the river are a problem in all seasons. Observations support that many technical problems are a result of high levels of sediment. Sediments fill the upstream catchment and block the intake and channel, hence reducing water flow and plant generation capacity. This causes lower production and thus lower income, and incurs costs for removing the sediment, as shown in Figure 3. During field visits, the first author observed soil erosion and sediments negatively impacting upstream catchment storage capacity at ten plants. Interviewees were asked to compare the importance of sedimentation to other sustainability factors 11 out of 17 plants reported that sediment-related problems were the most important factor negatively affecting the plant operation and sustainability.

Sediments also cause wear on mechanical seals that result in turbine water leakage and damage to the runner and nozzles. Interviewees also stated that soil erosion and flooding cause damage to structures, such as the turbine house, the channel, and intake. 
Table 3 shows these water-system related technical problems dealt with by respondents in 2018.

Table 3. Specific technical problems or damages reported to have occurred in 2018 at different power plants. Respondents could specify more than one type of problem. Three respondents answered that there had been no technical problem in the last year.

\begin{tabular}{cc}
\hline Occurred Technical Problem & Number of Plants Affected \\
\hline Turbine water leakage & 4 \\
Grid circuit break issues & 4 \\
Control unit burn issues & 3 \\
Runner and nozzle damage & 1 \\
Canal and intake damage & 1 \\
Generator bearing damage & 1 \\
Penstock rupture & 1 \\
Worn shaft sealing and head cover & 1 \\
Turbine house damage due to flooding & 1 \\
None & 3 \\
\hline
\end{tabular}

While water level variations depend primarily on rainfall, upstream water diversions are also a factor. In interviews, only one company identified water competition as an issue, which suggests that water competition was not a critical issue for most plants. However, observation indicates that water competition may increase as the rivers are increasingly used for domestic needs in nearby villages and cities for irrigation activities or for mining. According to Rwanda water laws of 2018, domestic usage has highest priority, followed by environmental protection, and, finally, economic activities [38]. Many companies designed plants using maximum available river discharge without considering the possible emergence of competitive uses of the river flow.

\subsection{Sustainability Factors for Electric Power System}

Plant operators and technical directors also indicated several technical factors that are within their control. More well-known aspects have been considered in the design of infrastructure or are dealt with through regular maintenance.

For most plants, the majority of maintenance work is performed by local workers (respondents indicated that in 14 of 17 hydropower plants, their maintenance work is done by company staff only whereas in three out of 17 hydropower plants it is done by company staff except in some cases). The use of local staff reduces the cost of repair and maintenance. These workers were typically trained by equipment suppliers and through on-the-job training while working at the plant. Some companies operate multiple plants and have a team providing technical service. The level of technical skills is thus largely sufficient to correct common problems (respondents indicated that in 15 of 17 plants, their staff received training from suppliers and on-the-job experience whereas in two of 17 plants, their staff received professional training and on-the-job training). However, there is a shortage of domestic experts who can carry out plant automation and control during plant operation and upgrading (respondents indicated that in nine of 17 plants, their staff has enough knowledge to carry out operation, maintenance, and upgrading whereas in eight of 17 plants, their staff doesn't have enough knowledge in plant automation and control). Ten respondents also stated a lack of in-country capacity building to keep pace with rapid international technology development. It was also observed that there are no in-country or in-region spare part suppliers and almost all respondents bought spare parts from overseas suppliers. Many companies maintain their own stock of spare parts, leading to premature-in worst case unnecessary-investment. Despite these issues, all respondents indicated that they can cover maintenance, operation, and equipment replacement costs through income from electricity sales.

Fifteen of the plants are privately owned. For these, interviewees bring up positive institutional factors: high commitment and ownership, simple procurement processes, 
and guaranteed sale of all electricity generated. Respondents perceive these as major contributors to the sustainability of their power plants.

\subsection{Consequences of Interconnection with National Grid}

To understand the positive economic situation, a closer look at the institutional setting is necessary. Out of the 17 surveyed plants, 16 are connected to the national grid and operate under a 25-year power purchase agreement (PPA) that sets the purchase price of the power produced by the plant. The PPAs are 'all production' agreements, meaning that the national grid will buy all electricity produced by the plants. The PPAs provide a key benefit to these plants: a stable sales price for all produced power. Therefore, income depends only upon how much electricity a plant can produce. Prices established by the PPAs are sufficient to cover operational and capital costs-in 16 of 17 of power plants, owners report positive net income on their plants.

Grid-connected, small-scale hydropower plants in Rwanda are typically connected to medium voltage (distribution systems are $25 \mathrm{kV}$ in most cases, with a few exceptions for short distances in high population areas) distribution circuits. Synchronous generators at the plant are connected to the grid through switches and a step-up transformer. During normal operation, plant generators are synchronous with the grid, which controls the generator speed. During blackouts (local or national), the generator loses synchronization and protection controls perform an emergency stop on water flow into the turbine to avoid a destructive over-speed condition. Emergency stops produce high stresses on equipmentboth rotating equipment and gates-as well as high currents and voltages in electrical components. These loads accelerate wear and failure rates of those components.

Distribution circuits in western Rwanda are often in heavily wooded areas. During high winds, vegetation may contact distribution wires, causes phase-to-ground and interphase faults. Protection devices on the distribution circuit sense these events and disconnect the circuit from the transmission system, causing a loss of voltage (a local 'blackout'), and a plant shutdown.

While a grid connection provides a stable sales price for produced power, connection to the national grid also subjects plant equipment to frequent shutdowns due to local blackouts. Twelve interviewees identified grid integration issues as an important technical problem (see Figure 2). The issue was further investigated through observations during the one-day plant field visits in rainy and dry seasons, and during the one-month field observation at one hydropower plant.

Figure 4 shows the results of monitoring one plant for one month. Unplanned plant stops due to grid problems occurred most frequently in the rainy season-on average, three times a day. Most stops last a few seconds to two minutes-typical outage times for ground faults-and it takes a plant three to six minutes to reconnect to the grid. Faults are often caused by weather conditions; windy conditions may cause tree branches to contact power lines or lightning may trigger protection circuits. In both cases, faults may be cleared quickly by an auto-recloser, or may take longer if crews must repair damage or remove tree branches. The institutional responsibility for maintaining distribution grids and clearing line corridors lies with REG, not the IPP. Equipment problems may also cause faults. Poor insulation or water seals may cause power lines to short circuit during heavy rains, or ground faults may occur due to poor ground protection at the plant.

The outage pattern is shown in the bottom left of Figure 4. We find that blackouts were caused by a variety of factors, including external causes mentioned above, poor maintenance of some power lines, and noncompliance of small-scale power plants to grid protection standards. 

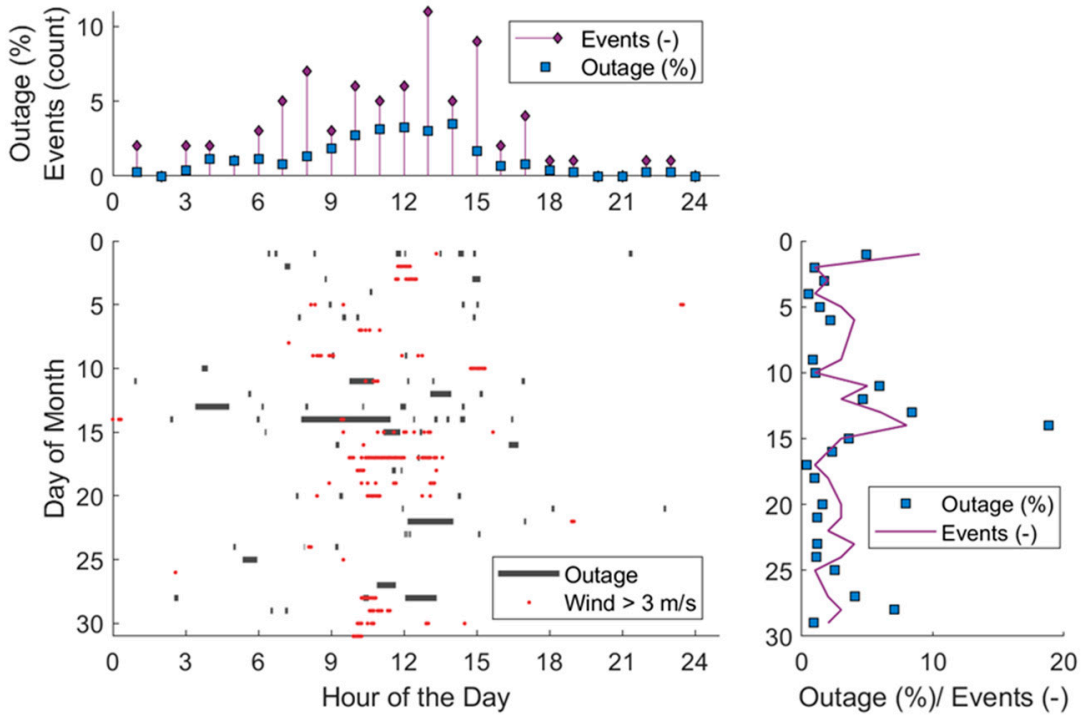

Figure 4. Data collected in the one-month field observation on unplanned plant stops due to grid tripping. Upper panel: Outage pattern by time of day-outages are more likely to occur during mid-day. Bottom left: One month of recorded outage data, overlaid with wind speed-windier times align with outage times. Right: Outage pattern by day of month—outages are random by day, but occur on 25 of 31 days.

\section{Discussion}

In light of previous research on small-scale hydropower plants in developing economy contexts, this study indicates that Rwanda is unique for its uncharacteristically high level of grid integration and the prevalence of private companies involved in the sector. Two other key features are the very high sediment load in rivers and the large seasonal change in river flow.

The individuals interviewed, most of whom work for private sector companies, presented a positive attitude toward the current development of the sector, as evidenced by their ability to cover costs, including capital retirement. The favorable institutional and regulatory conditions seem to have enabled the development and, in particular, the promise of economic stability offered by the current PPAs for grid-integrated systems [2,5]. Previous literature typically lists low income among the threats to sustainability, with difficulties in funding maintenance, repair, and re-investment as key issues [25,39,40]. Among the country's 25 small-scale hydropower plants, 24 are grid-connected and are not facing demand risks. Additionally, REG has not had the payment problems experienced with other national utility operators in East Africa [37].

So far, literature on small-scale hydropower plants for the sub-Saharan region has not dealt with the issue of whether on- or off-grid operation is preferable. When off-grid generation is needed to support energy provision in remote locations, a small hydropower plant is often considered a good choice [25]. However, our study finds that access to grid connection has attracted many IPPs to the development of small hydro, which increases private investment, freeing government capital for other public priorities. This development has been possible in Rwanda but, so far, has not happened to the same degree in neighboring countries or elsewhere in other developing economies $[19,40]$. Stronger development in Rwanda is likely a result of existing favorable policies, particularly feed-in-tariff regulations and stable PPAs, and existing ICT infrastructures in all parts of the country.

Our findings also indicate that studied plants have sufficient technical expertise to deal with most situations, whereas other studies of small-scale electric power systems in the East African region (on- and off-grid) often mention a lack of technical skills as reasons why systems fail to operate through their design life [22]. Multiple companies involved also operate more than one plant and can afford to employ skilled staff to service their systems. 
In terms of factors with a negative impact on sustainability, the seasonal variation in river discharge is not unique for Rwanda, but the choice of sizing systems according to maximum discharge, rather than adapting it to dry season average, is not commonly discussed elsewhere in literature on sub-Saharan Africa.

In line with previous studies from the region, soil erosion and concomitant high sediment loads represent serious problems that lead to additional maintenance costs and increased downtime [23]. However, Rwanda experiences a level of soil erosion that is high relative to comparative countries. The government has recently announced a new policy to combat soil erosion through agroforestry and forest restoration [38].

The water-related challenges are likely to increase in the coming decades. With climate change, the future rainfall patterns are uncertain. To the degree that there exists data on larger trends, the average temperature in Rwanda has increased by $0.35{ }^{\circ} \mathrm{C}$ per decade from 1971 to 2010 which was higher than the global average increase of $0.27^{\circ} \mathrm{C}$ per decade from 1979 to 2005 [41]. With the changing climate, the risk for extreme weather events, including very heavy rainfalls, may increase the risk of landslides.

Finally, water competition is likely to become a more acute challenge. The amount of water used in human activities is increasing with economic development, urbanization, and population growth. While water competition was not a challenge at the time of construction, and water use was regulated legally, IPPs did not consider a future increase in water use during plant design. Domestic water needs are prioritized in both the Rwanda Water Law of 2008 and of 2018 [35]. For future development of hydropower plants, actors in the sector need to investigate strategies to deal with water competition and the institutional regulation of human activities upstream.

\section{Conclusions}

This study has identified factors affecting the sustainability of 17 small-scale hydropower plants currently operating in Rwanda. Distinguishing between factors that are outside the control of plant owners and operators, and factors that they can control, we find the major positive factors to be: favorable existing regulations and policies, technical expertise among local staff to carry out plant operation and maintenance, and access to grid connection ensuring the economic viability of plants. However, river discharge drops in dry season, sediment load and soil erosion (especially in rainy season), and unplanned plant stops due to grid blackouts are the major negative factors affecting the sustainability of plants. These factors shorten the lifetime of turbines, reduce electricity production, and increase maintenance costs.

Based on these results, we conclude that the grid integration under the current institutional arrangements come with important benefits. Although there are technical issues that need further investigation and corrective actions, we recommend that the government of Rwanda maintains the conducive regulations to encourage IPPs to expand their production. To address the frequent shutdowns that are caused by grid tripping, we suggest IPPs should design plants with protection systems that comply with grid protection standards. There is a need for sector stakeholders to engage in a dialogue on how to ensure the regular maintenance of transmission lines and feeder lines from plants to grid, as well as clearing vegetation underlines to minimize grounding faults during rainy and windy weather.

The study indicates that water level is currently not a major challenge, but the seasonal drop in discharge and plant capacity factor raises questions about the suitable design of plants. We see the need for further research on the best plant designs to cope with seasonal variation and increased future water use for domestic, agricultural, and industrial needs. In addition, as increasing temperatures impact rainfall patterns, there will be a need to balance competing claims for water. The IPPs cannot control upstream activities leading to soil erosion, as erosion control is under the jurisdiction of the government of Rwanda. We suggest that there is a need for further research on upstream mitigation measures in dialogue with local farmers, and on design solutions to either reduce the amount of silt entering the plant, or the silt's effect on equipment and operation. 
Supplementary Materials: The following are available online at https:/ /www.mdpi.com/1996-107 3/14/4/826/s1.

Author Contributions: The first author G.G. has taken lead on all aspects of the study and writing process. The other authors have contributed as follows: Conceptualization, H.A., and D.Z.; methodology, H.A. and D.Z.; writing - original draft preparation, H.A. and D.Z.; writing-review and editing, H.A. and D.Z.; visualization, D.Z.; supervision, E.N.; project administration, E.N. All authors have read and agreed to the published version of the manuscript.

Funding: This research was funded by the World Bank through its sponsorship of the positions of the first and third author at the African Center of Excellence in Energy for Sustainable Development under the University of Rwanda, College of Science and Technology.

Institutional Review Board Statement: This study was approved by ethics committee of University of Rwanda.

Informed Consent Statement: We got permission to all companies involved in the study.

Acknowledgments: We wish to acknowledge the World Bank for sponsoring the research through the positions of the first and third author at the African Center of Excellence in Energy for Sustainable Development under the University of Rwanda, College of Science and Technology. The second and last author did not receive any specific funds for the project but is grateful to their home institutions for supporting their engagement with Rwandan colleagues.

Conflicts of Interest: The authors declare no conflict of interest. The funders had no role in the design of the study; in the collection, analyses, or interpretation of data; in the writing of the manuscript, or in the decision to publish the results.

\section{References}

1. Africa Energy Outlook 2019 World Energy Outlook Special Report; ci IEA Publications, 2019; p. 288. Available online: https: //webstore.iea.org/africa-energy-outlook-2019 (accessed on 30 December 2020).

2. Paish, O. Small hydro power: Technology and current status. Renew. Sustain. Energy Rev. 2002, 6, 537-556. [CrossRef]

3. World Small Hydropower Development Report. 2013. Available online: http://www.smallhydroworld.org/fileadmin/user_ upload/pdf/WSHPDR_2013_Final_Report-updated_version.pdf (accessed on 4 June 2020).

4. Rwanda Least Cost Power Development Plan (LCPDP) 2019-2040. Available online: https://www.reg.rw/fileadmin/user_ upload/LCPDP_REPORT_June_2019.pdf (accessed on 5 August 2019).

5. EDCL. Status of the Hydropower Sector in Rwanda; EDCL: Kigali, Rwanda, 2016; pp. 1-6. Available online: https://www.reg.rw/ fileadmin/user_upload/RwandeseHydropowerSectorStatusDECEMBE20.pdf (accessed on 3 March 2019).

6. Rwanda Energy Sector Review and Action Plan. 2013. Available online: https://www.afdb.org/fileadmin/uploads/afdb/ Documents/Project-and-Operations/Rwanda_-_Energy_Sector_Review_and_Action_Plan.pdf (accessed on 17 July 2019 ).

7. Regulations $\mathrm{N}^{\circ} 001 /$ Energy/Rura/2012 of 09/02/2012 on Rwanda Renewable Energy Feed in Tariff. 2012, pp. 1-10. Available online: https:/ / www.reg.rw/fileadmin/user_upload/REGULATIONS_ON_FEED_TARIFFS_HYDRO_POWER_PLANTS.pdf (accessed on 6 April 2019).

8. Unitited Nations Economic Commission for Africa. Rwanda Country Profile. 2015. Available online: https://www.uneca.org/ sites/default/files/images/ORIA/CP/rwanda.pdf (accessed on 4 April 2020).

9. Rwanda Energy Group. Electricity Access. Available online: https://www.reg.rw/what-we-do/access/ (accessed on 1 December 2019).

10. World Bank Group. Rwanda Economic Update: Lighting Rwanda. 2019. Available online: https:/ / openknowledge.worldbank. org / bitstream/handle/10986/31932/138242.pdf?sequence=1\&isAllowed=y (accessed on 26 May 2020).

11. Bensch, G.; Kluve, J.; Peters, J. Impacts of rural electrification in Rwanda. J. Dev. Eff. 2011, 3, 567-588. [CrossRef]

12. The Republic of Rwanda. 7 Years Government Programme: National Strategy for Transformation (NST1): 2017-2024. 2019. Available online: http:/ / www.minecofin.gov.rw / fileadmin/user_upload/NST1_7YGP_Final.pdf (accessed on 14 February 2019).

13. Energy Sector Strategic Plan Rwanda. 2015. Available online: https://www.mininfra.gov.rw/fileadmin/user_upload/new_ tender/Energy_Sector_Strategic_Plan.pdf (accessed on 22 June 2019).

14. Rural Electrification Strategy Rwanda. 2016. Available online: https:/ / www.mininfra.gov.rw / fileadmin/user_upload/aircraft/ Rural_Electrification_Strategy.pdf (accessed on 2 February 2020).

15. UN 2001: Indicators of Sustainable Development: Guidelines and Methodologies. Available online: http://www.un.org/esa/ sustdev/publications/indisd-mg2001.pdf (accessed on 4 December 2020).

16. Ilskog, E.; Kjellström, B. And then they lived sustainably ever after?-Assessment of rural electrification cases by means of indicators. Energy Policy 2008, 36, 2674-2684. [CrossRef]

17. Singh, V.K.; Singal, S.K. Operation of hydro power plants-a review. Renew. Sustain. Energy Rev. 2017, 69, 610-619. [CrossRef] 
18. Rajkarnikar, B.; Pyakurel, P.; Neopane, H.P. Sustainability Issues of Micro Hydropower Plants in Nepal Sustainability Issues of Micro Hydropower Plants in Nepal; 2011. Available online: https://www.researchgate.net/publication/294887897_Sustainability_Issues_ of_Micro_Hydropower_Plants_in_Nepal (accessed on 8 July 2020).

19. Nasution, M.A.; Ambarita, H.; Siregar, I. Social and technical barriers that affect the growth of small-scale hydropower independent power producers in Indonesia. IOP Conf. Ser. Mater. Sci. Eng. 2018, 420. [CrossRef]

20. Didik, H.; Bambang, P.N.; Asep, S.; Purwanto, Y.A. Sustainability Challenge of Micro Hydro Power Development in Indonesia. IOP Conf. Ser. Earth Environ. Sci. 2018, 147. [CrossRef]

21. Terrapon-Pfaff, J.; Dienst, C.; König, J.; Ortiz, W. A cross-sectional review: Impacts and sustainability of small-scale renewable energy projects in developing countries. Renew. Sustain. Energy Rev. 2014, 40, 1-10. [CrossRef]

22. Ahlborg, H.; Hammar, L. Drivers and Barriers to Rural Electrification in Tanzania and Mozambique-Grid Extension, Off-Grid and Renewable Energy Sources. In Proceedings of the World Renewable Energy Congress-Sweden, Linköping, Sweden, 8-13 May 2011; Volume 57, pp. 2493-2500. [CrossRef]

23. Luis, J.; Sidek, L.M.; Desa, M.N.M.; Julien, P.Y. Sustainability of hydropower as source of renewable and clean energy. IOP Conf. Ser. Earth Environ. Sci. 2013, 16. [CrossRef]

24. Thakur, R.; Kumar, A.; Khurana, S.; Sethi, M. Correlation development for erosive wear rate on pelton turbine buckets. Int. J. Mech. Prod. Eng. Res. Dev. 2017, 7, 259-274. [CrossRef]

25. Kaunda, C.S.; Kimambo, C.Z.; Nielsen, T.K. Potential of Small-Scale Hydropower for Electricity Generation in Sub-Saharan Africa. ISRN Renew. Energy 2012, 2012, 1-15. [CrossRef]

26. Ahlborg, H.; Sjöstedt, M. Small-scale hydropower in Africa: Socio-technical designs for renewable energy in Tanzanian villages. Energy Res. Soc. Sci. 2015, 5, 20-33. [CrossRef]

27. Bhandari, R.; Saptalena, L.G.; Kusch, W. Sustainability assessment of a micro hydropower plant in Nepal. Energy Sustain. Soc. 2018, 8. [CrossRef]

28. Pigaht, M.; van der Plas, R.J. Innovative private micro-hydro power development in Rwanda. Energy Policy 2009, 37, 4753-4760. [CrossRef]

29. Geoffrey, G.; Zimmerle, D.; Ntagwirumugara, E. Small Hydropower Development in Rwanda: Trends, Opportunities and Challenges. IOP Conf. Ser. Earth Environ. Sci. 2018, 133, 012013. [CrossRef]

30. Sangal, S.; Singhal, M.K.; Saini, R.P. Hydro-abrasive erosion in hydro turbines: A review. Int. J. Green Energy 2018, 15, 232-253. [CrossRef]

31. Khurana, S.; Varun; Kumar, A. Silt erosion study on the performance of an impulse turbine in small hydropower. Int. J. Ambient Energy 2016, 37, 520-527. [CrossRef]

32. World Population Review. Rwanda Population. 2020. Available online: https://www.worldometers.info/world-population/ rwanda-population (accessed on 20 January 2020).

33. World Climate Guide. Available online: https://www.climatestotravel.com/climate/rwanda (accessed on 20 January 2020).

34. Mikkelsen, B. Methods for Development Work and Research: A New Guide for Practitioners, 2nd ed.; Sage Publications: New Dehli, Indian; Thousand Oaks, CA, USA; London, UK, 2005.

35. Rwanda Law on Environment 2018. Available online: https://waterportal.rwb.rw/sites/default/files/2018-10/Water\%20law\% 20gazetted\%2C2018.pdf (accessed on 4 June 2020).

36. Rwanda Ministry of Environment. Erosion Control Mapping Report. 2020. Available online: https://waterportal.rwb.rw/sites/ default/files / 202005/Erosion\%20Control\%20mapping\%20report_2020.pdf (accessed on 22 October 2020).

37. Karamage, F.; Zhang, C.; Ndayisaba, F.; Shao, H.; Kayiranga, A.; Fang, X.; Nahayo, L.; Nyesheja, E.M.; Tian, G. Extent of cropland and related soil erosion risk in Rwanda. Sustainability 2016, 8, 609. [CrossRef]

38. Rwanda National Forestry Policy. 2018. Available online: http://www.rwfa.rw/fileadmin/user_upload/Rwanda_National_ Forestry_Policy_2018.pdf (accessed on 1 February 2020).

39. Korkovelos, A.; Mentis, D.; Siyal, S.H.; Arderne, C.; Rogner, H.; Bazilian, M.; Howells, M.; Beck, H.; De Roo, A. A geospatial assessment of small-scale hydropower potential in sub-saharan Africa. Energies 2018, 11, 3100. [CrossRef]

40. Hartung, H.; Biririza, E.M.; Jagwe, W.; Lenz, F. Advanced Scoping for Technical Capacity Building on Small Hydropower in East Africa. 2015, pp. 1-38. Available online: http://www.euei-pdf.org/sites/default/files/field_publication_file/EAC_Advanced_Scoping_ on_Techncial_Capacity_Building_for_Small_Hydropower_in_East_Africa_Final_Report.pdf (accessed on 4 February 2019).

41. Rwanda Climate Change Portal. Available online: http:/ / climateportal.rema.gov.rw/node/22 (accessed on 1 February 2020). 